\title{
Discrimination of hot versus cold avalanche deposits: Implications for hazard assessment at Mount Meager, B.C.
}

\author{
M. L. Stewart ${ }^{1}$, J. K. Russell ${ }^{1}$, and C. J. Hickson ${ }^{2}$ \\ ${ }^{1}$ Igneous Petrology Laboratory, Department of Earth and Ocean Sciences, University of British Columbia, Vancouver, British \\ Columbia, Canada \\ ${ }^{2}$ Pacific Division, Geological Survey of Canada, Vancouver B.C., Canada
}

Received: 5 February 2003 - Revised: 26 May 2003 - Accepted: 29 May 2003

\begin{abstract}
The surficial deposits surrounding the Mount Meager volcanic complex include numerous avalanche deposits. These deposits share many attributes: (a) they are nearly monolithologic and comprise mainly intermediate volcanic rock clasts, (b) they lack internal structure, and (c) they are very poorly sorted. Despite these similarities, the avalanche deposits represent two distinct processes. Mass wasting of the Mount Meager volcanic edifice has produced cold rock avalanche deposits, whereas gravitational collapse of active lava domes and flows has produced hot block and ash avalanche deposits. The ability to discriminate between these "hot" and "cold" avalanche deposits is a critical component in the assessment of hazards in volcanic terranes. Hot block and ash avalanche deposits can be distinguished by the presence of radially-oriented joints, breadcrust textures, and incipient welding, which are features indicative of high emplacement temperatures. Conversely, rock avalanche deposits resulting from mass wasting events may be distinguished by the presence of clasts that preserve pre-depositional weathering and jointing surfaces. Volcanic avalanches are mechanically similar to rock avalanches but pose a greater hazard due to high temperatures, increased fluidization from degassing and the potential to decouple highly mobile elutriated ash clouds. The increasing use of hazardous regions such as the Lillooet River valley requires more reliable risk assessment in order to minimize losses from future hazardous events.
\end{abstract}

\section{Introduction}

The margins of convergent plates commonly have landscapes that feature large volcanic edifices (in particular, stratovolcanoes) situated in regions of extreme topographic relief. They represent one of the most hazardous and, potentially, high risk natural environments on the planet. Volcanic eruptions

Correspondence to: M. L. Stewart

(mstewart_geo@hotmail.com) represent an obvious hazard and, in many instances, the nature or magnitude of these volcanic hazards can be substantially modified or amplified by the mountainous terrain. For example, lava flows and domes that might represent lower risk volcanic events can be quickly transformed into explosive avalanches of pyroclastic material when forced onto steep slopes (e.g. Rose et al., 1976; Bardintzeff, 1984; Mellors et al., 1988; Sato et al., 1992; Calder et al., 1999). Avalanches of cold bedrock are also a common hazard associated with these landscapes. The volcanic edifices (i.e. stratovolcanoes) constitute high-relief, unstable landmasses that serve as ideal sources to rock avalanches (Ui, 1983; Voight et al., 1983; Siebert, 1984). This interplay between volcanism and mass wasting produces a stratigraphic succession that is rich in avalanche deposits. These deposits represent both volcanic and mass wasting events. In this paper we refer to avalanches of hot pyroclastic material that are explicitly related to volcanic activity as "block and ash avalanches". The term "rock avalanche" is used to refer to cold non-volcanic avalanches of bedrock.

Block and ash avalanche and rock avalanche deposits that derive from volcanic edifices can share several traits that make them superficially similar. Firstly, they comprise mainly poorly sorted, angular rock fragments and form unstructured deposits (Cas and Wright, 1988). Secondly, both deposit types can be nearly monolithologic. Our objective is to advance criteria that are already established in the volcanological literature for discriminating between these "hot" and "cold" avalanche deposits. Accurate identification of these deposits is requisite for effective hazard planning. The criteria for separating these two types of deposits are illustrated using a case study based on deposits from Mount Meager, British Columbia. These deposits fill the Lillooet River valley, below the Mount Meager volcanic complex situated in the Coast Mountains of Southwestern British Columbia (Fig. 1). 


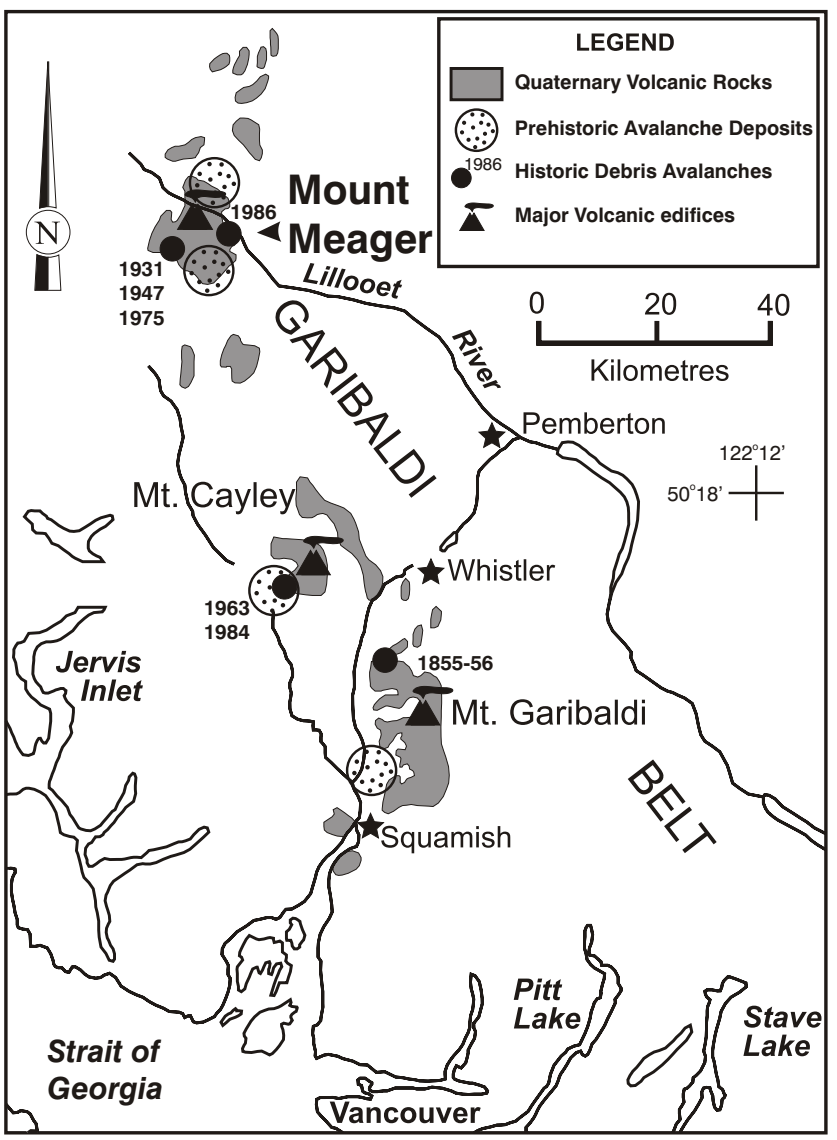

Fig. 1. Location of Mount Meager volcanic complex is shown against the distribution of other Quaternary volcanic edifices in the Garibaldi belt of southwest British Columbia. Locations of prehistoric and historic rock avalanche deposits associated with major volcanic edifices are also shown (after Clague and Turner, 2003).

\section{Geologic setting}

The Garibaldi volcanic belt hosts Quaternary stratovolcanoes situated in southwestern British Columbia and includes Mount Meager, Mount Cayley, and Mount Garibaldi (Fig. 1; Green et al., 1988). The Mount Meager volcanic complex (MMVC) preserves a number of deeply eroded volcanic centres that have been active during the past $2.2 \mathrm{Ma}$ (Read, 1978) (Table 1). The geology of the MMVC is well-described by Read (1978), Stasiuk and Russell (1989, 1990), Hickson et al. (1999) and Stewart et al. (2002). The most recent eruption in the belt is dated at $2360 \mathrm{yr}$. BP and derives from the MMVC (Clague et al., 1995). The eruption produced a sequence of dacitic volcanic deposits that overlie basement rocks of the southern Coast Belt including Triassic metamorphic supracrustal rocks, and Tertiary monzonite intrusions and constitute the Pebble Creek formation (PCF) (Read 1978; Stasiuk and Russell, 1990; Stasiuk et al., 1996; Hickson et al., 1999). The Plinth assemblage is the next oldest volcanic deposits dating to between 90000 to $100000 \mathrm{yr}$. BP (Read, 1978).
This region of the Coast Mountains has been characterized by rapid rates of uplift over the past $4 \mathrm{Ma}$ (Farley et al., 2001), which has led to relatively high rates of erosion. Thus, the Mount Meager volcanic complex is highly dissected and is presently perched above 1100-1200 m elevation (Fig. 2), well above the present day erosion surface marked by the Lillooet River (400-500 m elev.).

\section{Avalanche deposits}

\subsection{Block and ash avalanche deposits}

Volcanic deposits found within the Lillooet River valley mainly belong to the Pebble Creek formation (Read, 1978; Stasiuk and Russell, 1989; Hickson et al., 1999). This formation includes pyroclastic fall and pumiceous pyroclastic flow deposits associated with a sub-Plinian eruption as well as block and ash avalanche deposits deriving from Merapistyle eruptions (Stasiuk and Russell, 1989; Hickson et al., 1999). The inferred vent to the eruption is situated in a cirque immediately below bluffs of Plinth assemblage (Fig. 2). Pumiceous pyroclastic flow and block and ash avalanche deposits of the Pebble Creek eruption filled the paleo-Lillooet river valley. These are now dissected by the current Lillooet river (Figs. 2-4), exposing much of the stratigraphy.

The source of the block and ash avalanche deposits was erupting dacite lava flows and or lava domes. These flows or domes collapsed under gravitational or explosive stresses on the steep-sided slopes of the volcano (Hickson et al., 1999). The main features of these deposits are summarized in Table 2 . They are very poorly sorted and nearly structureless and show rare clast alignment. They vary from strongly welded (Fig. 5d) to poorly indurated (Fig. 5a) or unconsolidated. Particles range from ash-size fragments to clasts greater than $10 \mathrm{~m}$ in diameter (Fig. 5a). Textures and structures within clasts are highly variable.

Volcanic clasts are angular to subrounded; some blocks may show prominent flow-banding defined by concentrations of vesicles (Fig. 5a). Subrounded clasts in some deposits have a significant proportion of intermediate to large sized blocks $(>50 \%$ ) containing joint sets that are oriented perpendicular to the exterior surface (Fig. 5b, c). Some smaller blocks also show radially oriented joint sets. A number of blocks also show concentric sets of joints. The interior set is relatively coarse and comprises widely spaced joints, whereas the outer set is finer-scale and features more closely spaced joints (Fig. 5b,c). Occasionally these fine joints are expressed on the surface of the blocks as fine crenulated fractures. Another subset of subrounded blocks are "breadcrust" textured (Fig. 5e). The exterior surfaces of these blocks feature pervasive irregular fractures up to $3 \mathrm{~cm}$ deep that completely cover the surface and are oriented normal to the exterior clast surface. 
Table 1. Summary of avalanche events, volcanic cycles and related events from historical records (Read, 1978; Hickson et al, 1999). Included are the number of deposits mapped in the Mount Meager volcanic complex, and the number of individual events recognized from those deposits. History records a large number of major rock avalanche events in the Mount Meager volcanic complex, but deposits from similar prehistoric events are poorly preserved in the geologic record. No rock avalanche deposits are recognizable prior to the end of the Fraser glaciation (10000 yr. BP). Deposits of large volume volcanic cycles prior to the glaciation have been mapped throughout the complex (Read, 1978). Major volcanic cycles occur approximately every 250000 to 300000 years. The Pebble Creek formation is sufficiently young to have escaped erosion from glaciation and, thus, preserves a nearly complete record of events within that eruption cycle. Note the close association in time between the Pebble Creek volcanic cycle and production of avalanches on the surrounding slopes of Plinth peak

\section{EVENT}

\section{AGE $\begin{gathered}\text { GEOLOGIC DEPOSITS } \\ \text { UNITS }\end{gathered}$}

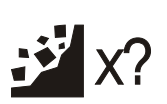

Recent Events - regular season occurrences of rockfall activity, debris flows and minor avalanches.

; $\times 5$

Major Historic Events - significant recorded

events resulting in the loss of life, infrastructure damage or flooding.

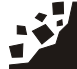

Devastation assemblage - major event deriving from devastator peak. Deposits fill devastation creek.

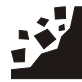

Plinth Assemblage - large $\left(10^{8} \mathrm{~m}^{3}\right)$ syn- to post-volcanic avalanche deriving from Plinth peak.

Pebble Creek Formation - thick (>100m) accumulations of Volcanic avalanche

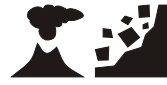

(pyroclastic flow) deposits from the Pebble

Creek eruption event.

Plinth Assemblage - syn-eruptive avalanche

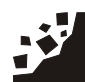

Plinth Assemblage - small exposure of Plinth derived avalanche directly underlying pebble creek volcanic deposits.

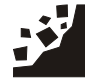

Pylon Assemblage - large $\left(10^{8} \mathrm{~m}^{3}\right)$ undated avalanche from pylon peak.

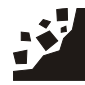

Plinth Assemblage - large landslide deriving from the south flank of Mount meager.

Fraser Glaciation - peak ice advance at $15,000 \mathrm{yr}$. , essentially ending at 10,000 yr.

Plinth Assemblage and Capricorn

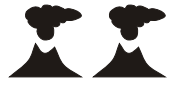

Assemblage - major edifice building eruption episodes. Deposits are eroded down to subvolcanic intrusive roots of the volcanoes.

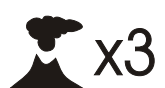

Pylon Assemblage - major edifice-building eruptive center. Appears to be extremely long-lived.

Devastator Assemblage - age unknown.

Unsubdivided Pliocene Assemblages remnants of early deposits of the embryonic Mount Meager volcanic complex.
$<10$

undoc.

$<70$ 


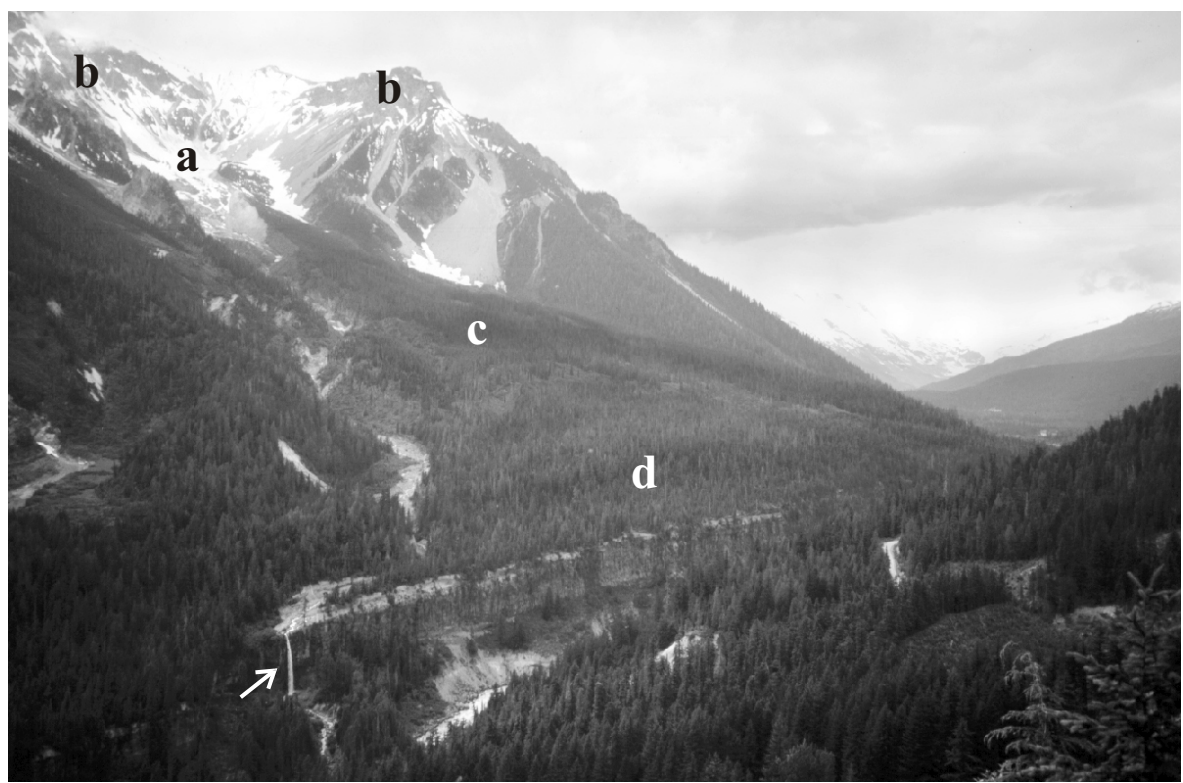

Fig. 2. Westward viewing photograph shows major topographic features of the northern slopes of Mount Meager and the Lillooet River valley. The main elements include: (a) location of vent to the $2360 \mathrm{yr}$ BP eruption responsible for Pebble Creek volcanic deposits, (b) outcrops of Plinth assemblage volcanic rocks situated immediately above vent (Plinth Peak is above the left hand corner of photo), (c) Pebble Creek formation lava flow extending from the vent into the present-day Lillooet River valley, and (d) outcroppings of densely welded block and ash flow deposits of the Pebble Creek formation in the Lillooet River valley. The waterfall (arrow) is approximately $40 \mathrm{~m}$ in height.

Table 2. Summary of critical properties for discrimination of avalanche deposits produced by mass wasting or volcanic processes. Rock avalanche deposits represent mass wasting events deriving from volcanic peaks of the Mount Meager volcanic complex, whereas, Merapitype block and ash avalanche deposits result directly from volcanic eruption (Hickson et al., 1999). Deposits share mesoscopic similarities but are distinguished by several finer-scale diagnostic features (cf. 3.4). These features show one of the avalanche deposits at Mount Meager to have a mixed origin

\begin{tabular}{|c|c|c|c|c|}
\hline Characteristic & (A) Block and Ash Avalanche & (B) Rock Avalanche & (C) Mixed Avalanche & $\begin{array}{r}\text { Diagnostic }^{1} \\
\text { (Ranking) }\end{array}$ \\
\hline Origin & Lava Collapse & Mass Wasting & as in $\mathrm{A}$ and $\mathrm{B}$ & \\
\hline Source & Pebble Creek and Plinth Eruptions & Plinth Assemblage Deposits & as in $\mathrm{A}$ and $\mathrm{B}$ & \\
\hline Age & 2360 and $90000 \mathrm{yr}$. BP & various & 2360 yr. BP & \\
\hline Lithology & $\begin{array}{c}\text { Monolithologic; } \\
>90 \% \text { Pebble Creek volcanic clasts }\end{array}$ & $\begin{array}{l}\text { Monolithologic; } \\
>90 \% \text { Plinth clasts }\end{array}$ & $\begin{array}{l}\text { Heterolithic; Plinth } \\
\text { and Pebble Creek clasts }\end{array}$ & \\
\hline Sorting & none & none & none & \\
\hline Internal Structure & none to minor clast alignment & none & none & \\
\hline Induration & $\begin{array}{l}\text { Unconsolidated to indurated } \\
\text { or strongly welded }\end{array}$ & Unconsolidated & Unconsolidated & $\mathrm{S}$ \\
\hline Clast Shape & Angular and subrounded & Angular & as in $\mathrm{A}$ and $\mathrm{B}$ & $?$ \\
\hline Clast Surface & Smooth to rough & Rough, fractured & as in $\mathrm{A}$ and $\mathrm{B}$ & $\mathrm{W}$ \\
\hline Clast Features & $\begin{array}{l}\text { Breadcrust textured surface, } \\
\text { radially-oriented joints }\end{array}$ & Joint bounded surfaces & as in $\mathrm{A}$ and $\mathrm{B}$ & $\mathrm{S}$ \\
\hline
\end{tabular}

${ }^{1} \mathrm{~S}$ - strong evidence; W - weak evidence; ? - possible evidence

\subsection{Rock avalanche deposits}

The stratigraphic sections shown in Fig. 4 contain three rock avalanche deposits. An older rock avalanche underlies the Pebble Creek volcanic deposits (Fig. 4, Sect. A). A second small $15 \mathrm{~m}$ thick avalanche deposit lies within Pebble Creek formation block and ash avalanche stratigraphy
(Fig. 4, Sect. B). A third rock avalanche deposit outcrops on the north side of the Lillooet River opposite Plinth Peak (Figs. 3 and 4) and mantles the south-facing slopes up to an elevation of $880-900 \mathrm{~m}$. This latter deposit has a width of at least $3.4 \mathrm{~km}$. At its western extent this rock avalanche directly overlies thick pumice beds of the Pebble Creek formation. At lower elevations in the Lillooet River valley, this 

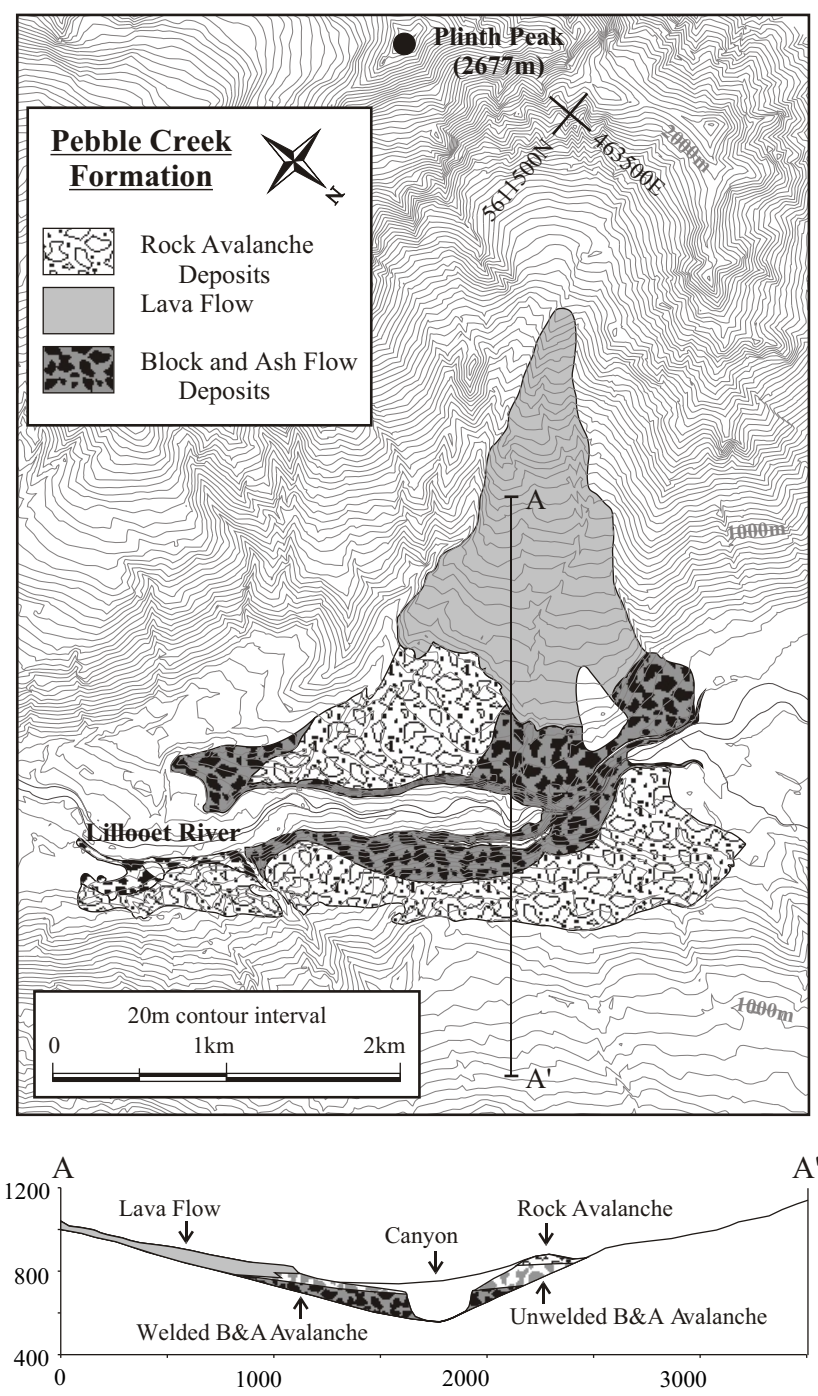

Fig. 3. Geological map for the area situated north of Mount Meager and along the Lillooet River. Map legend includes volcanic and rock avalanche deposits within the Pebble Creek Formation, as defined by Hickson et al. (1999) and Stewart et al. (2002). A large gorge extending southeast of keyhole falls cuts through and exposes much of the Pebble Creek stratigraphy. Avalanches remained relatively confined within the valley due to the steep slopes surrounding the volcano. (Elevation contours are given in m.a.s.1.)

avalanche was deposited on the irregular upper surfaces of the Pebble Creek block and ash flows. There is no paleosol developed on this lower contact and it is unclear whether the contact is erosional or preserves the original upper surface of the underlying deposit.

The rock avalanche deposits share many of the characteristics found in the block and ash avalanche deposits (Table 2). They are unconsolidated, very poorly sorted and show no discernible internal structure; clasts are angular, can be as large as $2.5 \mathrm{~m}$ in diameter, and are matrix supported (Fig. 6). The deposits are nearly monolithologic and the dominant clast type is massive dacite. These clasts derive from the volcanic rocks that make up Plinth Peak. Whilst most clasts are an-

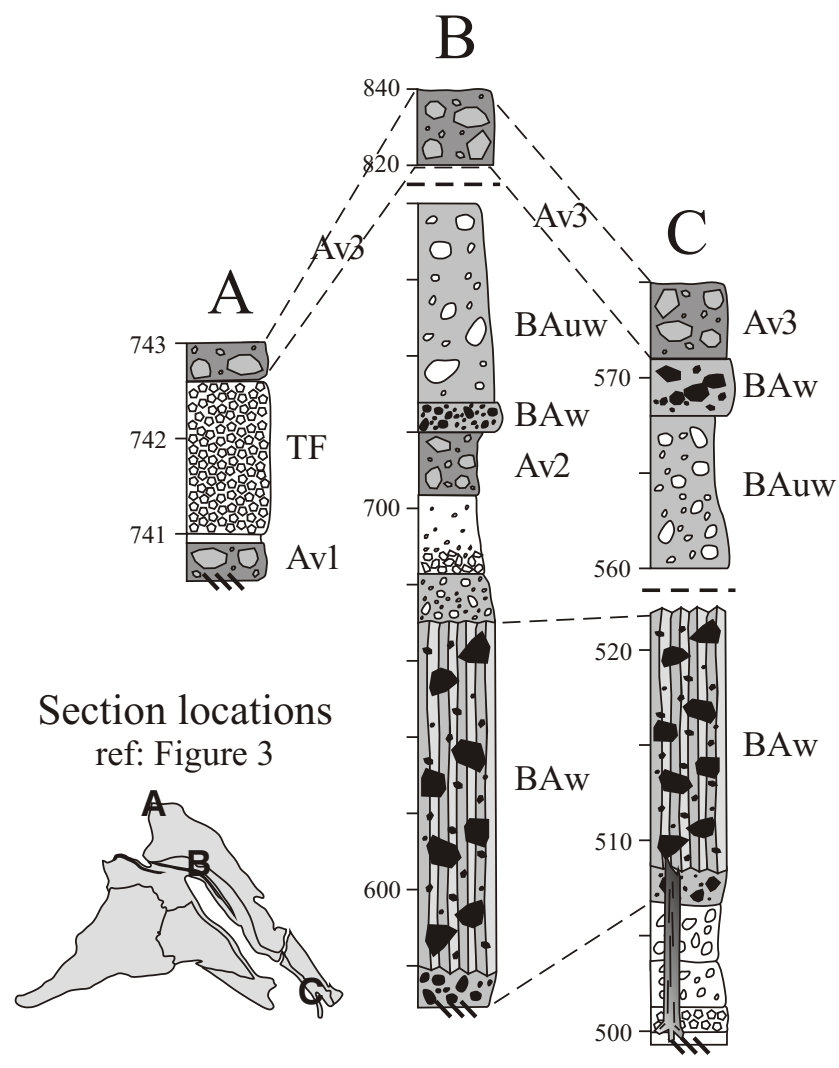

Fig. 4. Schematic stratigraphic sections summarizing distributions and relationships of rock avalanche (Av) and volcanic deposits (BAw, welded block and ash avalanche deposits; BAuw, unwelded block and ash avalanche deposits; PF, pumiceous pyroclastic flows; TF, tephra fallout) of the Pebble Creek formation. Section A: western limit of a large rock avalanche deposit overlying Pebble Creek pyroclastic fall (Av3). A pre-eruptive rock avalanche (Av1) lies at the base of this same section. Section B-C: Unwelded (BAuw) and welded (BAw) block and ash avalanche deposits form a thick, wide fan below the eruption vent (B) that thins downstream (C). A small rock avalanche (Av2) deriving from Plinth Peak is exposed within the block and ash avalanche deposits in Section B.

gular, some large blocks feature flat, regular joint or parting surfaces that are sometimes oxidized and are inferred to be columnar joint faces (Fig. 6b). In many instances, these regular joint surfaces terminate against freshly broken surfaces.

\subsection{Mixed block and ash and rock avalanche deposits}

The stratigraphy within the Lillooet River valley also includes an avalanche deposit that shows features that are found in both block and ash avalanche and rock avalanche deposits (Table 2). Specifically, this unit is poorly sorted, unstructured and comprises almost exclusively volcanic clasts. However, the deposit features discontinuous patches of primarily Plinth-derived fragments juxtaposed with sections containing mainly Pebble Creek Formation clasts. These two clast types appear concordant within the deposit, and there are no consistent vertical or horizontal gradations in clast 

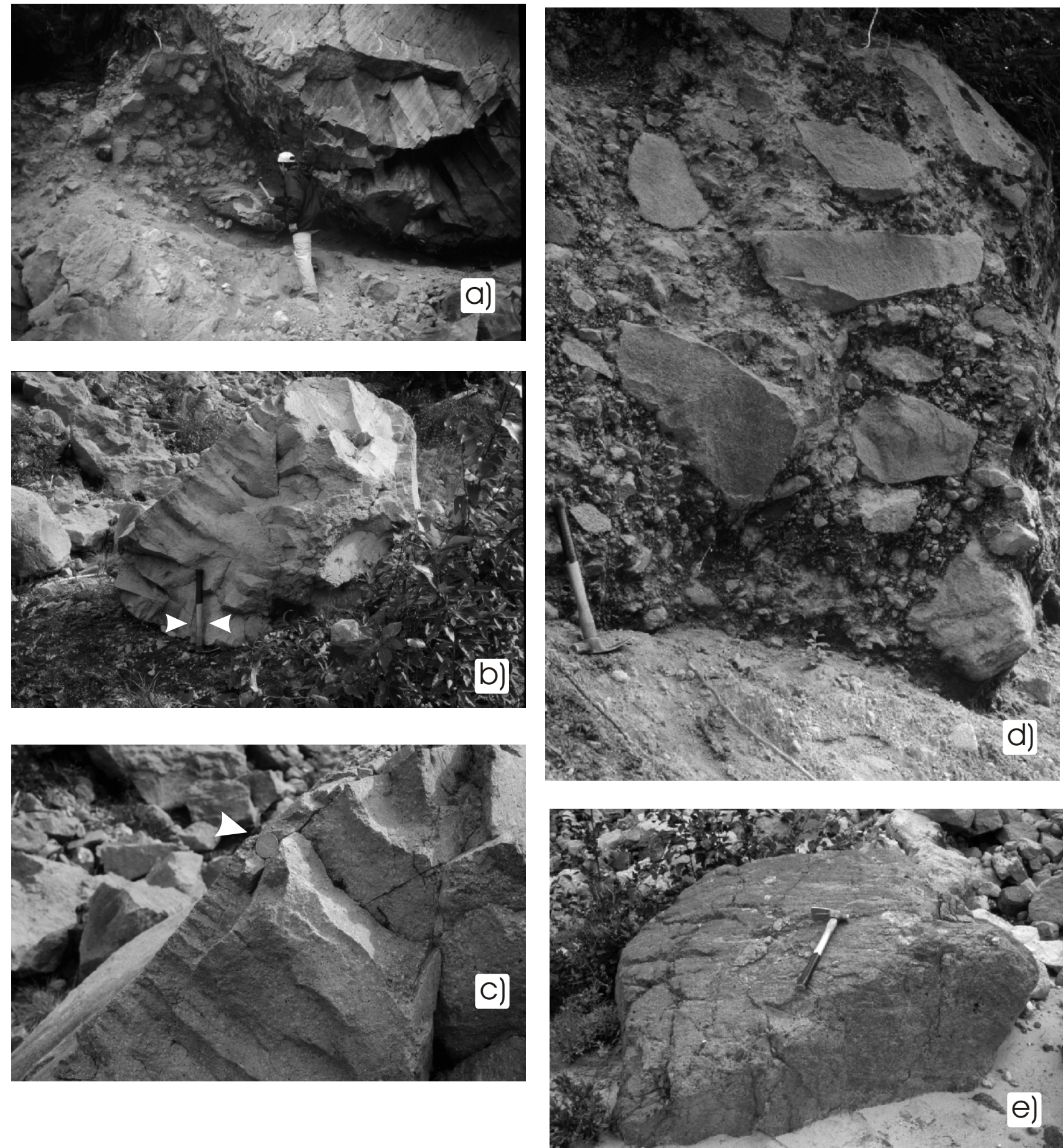

Fig. 5. Field photographs of block and ash avalanche deposits derived from collapse of lava flows or domes. These images document features which are diagnostic of an avalanche that was emplaced hot, including: (a) large (>10 m), massive, flow-banded block of dacite surrounded by poorly indurated, unsorted matrix, (b) coarse-scale, radially-oriented prismatic jointing in a large block, (c) fine-scale jointing superimposed on coarse jointing, (d) angular blocks in moderately welded block and ash flow facies and (e) delicate "bread-crust" surface textures (hammer is $45 \mathrm{~cm}$, coin is $2.5 \mathrm{~cm}$ ).

types. Clasts deriving from Plinth Peak are angular, pebble to boulder size clasts, with oxidized and irregular fractured surfaces. Juvenile Pebble Creek formation clasts are as large as $1.5 \mathrm{~m}$ and include dense pumice, dense black vitric and flow banded clasts. These clasts commonly preserve delicate volcanic textures such as breadcrusted surfaces (Fig. 6e). 

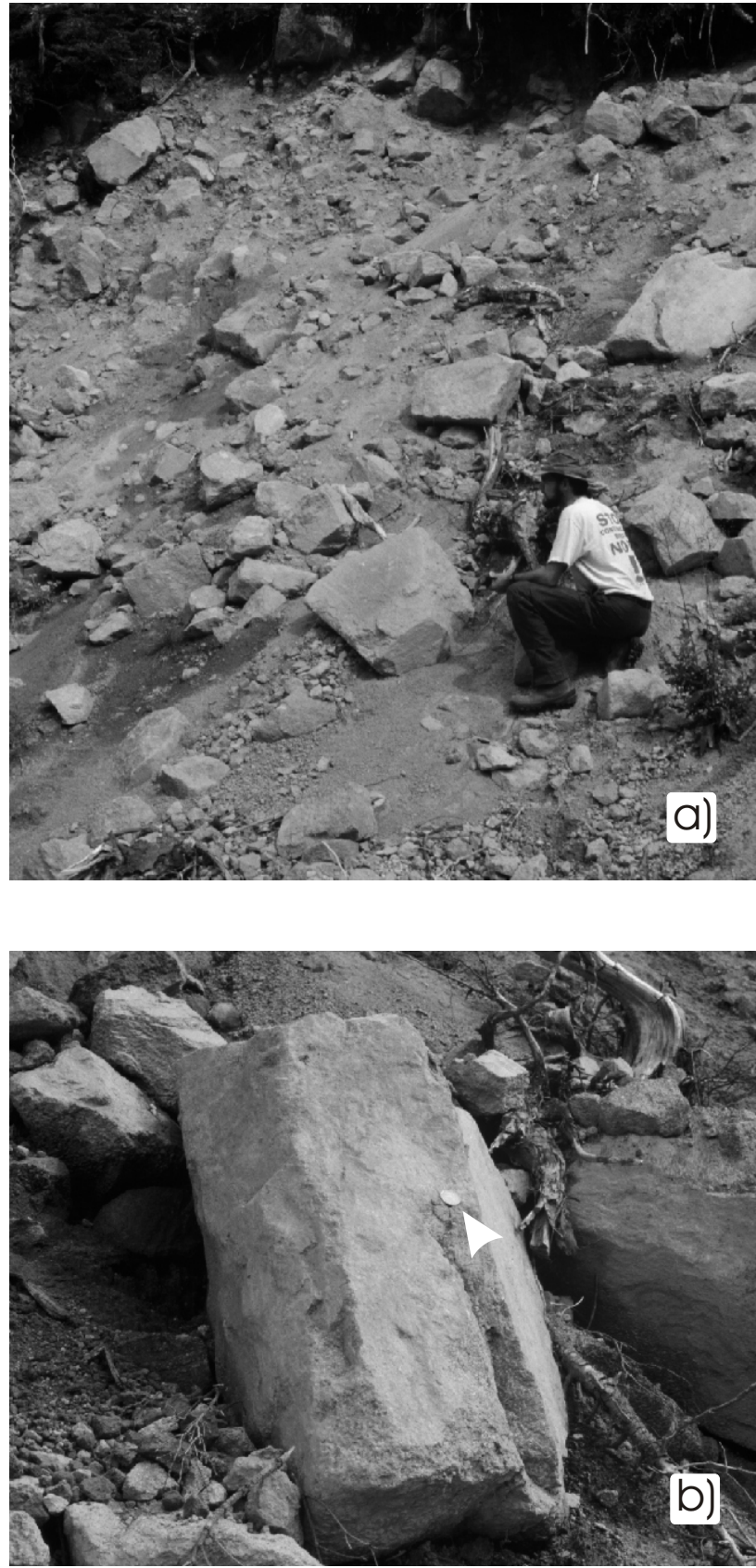

Fig. 6. Field photographs of cold rock avalanche deposits derived from mass-wasting of Plinth Peak showing: (a) unconsolidated, matrix supported and very poorly-sorted character of these deposits and (b) a detailed view of a block showing preservation of original cooling joint surfaces (coin is $2.5 \mathrm{~cm}$ ).

3.4 Distinguishing hot (block and ash) versus cold (rock) avalanche deposits

Block and ash avalanche and rock avalanche deposits within volcanic terrains share many attributes: (a) they are poorly sorted, (b) they lack internal structure, (c) they vary from unconsolidated to indurated, (d) they are virtually monolitho-

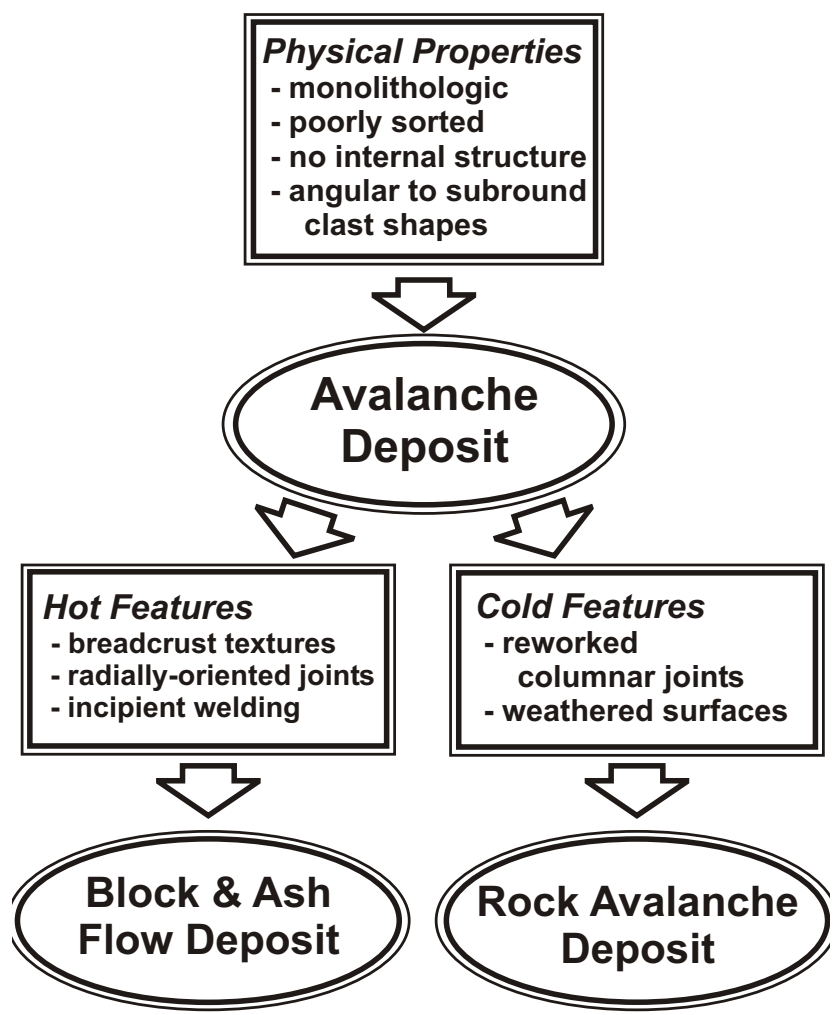

Fig. 7. Flow chart showing relationship between field characteristics (rectangles) of avalanche deposits and the inferred origins (ellipses). Rock avalanche deposits derived from mass wasting of volcanic edifices share many of the general traits of hot block and ash avalanches. However, careful and detailed mapping of these deposits can provide a number of features that rigorously discriminate between avalanches that are volcanic in origin and those arising from mass wasting processes.

logic, and (e) the clasts are volcanic in composition (Table 2). The latter two traits are inherited directly from the avalanche source, namely, a stratovolcano dominated by intermediate volcanic rocks. These features cause the rock avalanche deposits to resemble primary volcanic deposits (i.e. block and ash avalanche deposits).

Block and ash avalanche deposits are best distinguished by features indicative of high emplacement temperatures (Fig. 7). Firstly the Plinth block and ash avalanche deposit contains superb examples of lava blocks with prominent radially-oriented joint sets (Fig. 5b, c). These joints result from volume changes at the melt-glass transition during cooling of the clast. They are a direct indication that the clast temperatures at the time of deposition were above the glass transition temperature $\left(T_{g}\right)$. Their orientation perpendicular to the exterior of the clast indicates that the joints formed after the original fragmentation event. Indeed, the delicate nature of the radially-oriented joint sets strongly suggests that they probably formed after the avalanche came to rest.

Secondly, the presence of "breadcrust" textured blocks within unwelded portions of the Pebble Creek block and ash 
avalanche deposits (Fig. 5e) is also indicative of high emplacement temperatures. The breadcrust texture comprises an irregular set of fractures or joints that are oriented perpendicular to the clast exterior and that penetrate several centimeters into the clast. The texture results where the exterior of a block has cooled through the glass transition temperature but the interior remains hot and viscous. As the interior lava continues to exsolve a gas phase, the block expands causing the brittle exterior shell to fracture (Walker, 1969; Cas and Wright, 1988). The breadcrust texture is also a delicate feature that is unlikely to have survived transport and, therefore, is a strong indicator that the deposit came to rest at temperatures greater than $T_{g}$.

Our third criteria is the presence of incipient welding in portions of the deposit as illustrated by the Pebble Creek block and ash flow deposit (Fig. 5d). The glassy matrix anneals under the combined effects of lithostatic load and temperature. Essentially, if the deposit is above the rheological $T_{g}$ (Dingwell and Webb, 1990) and the load is sufficiently high, the glass particles will anneal and flow fast enough to create a cohesive deposit before cooling. Welding can be considered diagnostic of hot emplacement temperatures.

Evidence for the 'cold' origins of rock avalanches derived from volcanic edifices can be elusive at best; commonly, there is only an absence of evidence for a 'hot' origin. Many of the blocks in the Mount Meager avalanche deposits have faces defined by joint surfaces that are weathered or oxidized (Fig. 6b). These joints are inferred to be columnar joints formed during the original cooling of the volcanic source rock. Many of the blocks show joint surfaces that are terminated by fresh irregular broken edges formed during transport. The cooling joints and weathering surfaces predate transport, which suggests that the avalanche material derives from a cold, weathered source.

Using the criteria introduced above (Table 2) we were able to recognize a deposit which contained features indicative of both a hot block and ash avalanche and a cold rock avalanche (cf. Sect. 3.3). Clasts in this deposit derive from two distinct sources including a hot lava dome or lava flow and cold volcanic bedrock. The deposit likely formed from the conjoint failure and mixing of these source materials creating a unique type of mixed avalanche.

\section{Hazard and risk implications}

\subsection{Rock avalanches}

Rock avalanches are mass wasting events affecting oversteepened portions of the volcanic edifice (Ui, 1983; Siebert, 1984). They are driven by gravitational stresses (Erismann and Abele, 2001) induced by tectonic uplift and exhumation. Once an avalanche has been initiated, flow is governed by the conversion of gravitational potential energy to kinetic energy with friction acting against flow. That kinetic energy is used to supply momentum (velocity) and further mechanical breakdown of particles.
Long runout distances of avalanches exceed the expected travel distances for flow governed by frictional forces alone (Scheidegger, 1973; Hsü, 1975). Runout distances are positively correlated with the volume of the avalanche (Hsü, 1975; Ui, 1983; Corominas, 1996). Long run-out distances can result from acoustic fluidization (Melosh, 1979; Hungr, 1990; Erismann and Abele, 2001) and may be assisted by a lubricating medium (Ui, 1983; Siebert, 1984; Erismann and Abele, 2001). Indeed, run-out distances in excess of $100 \mathrm{~km}$ have been documented in steep volcanic terranes (e.g. Stoopes and Sheridan, 1992).

At Mount Meager, rock avalanches may have exploited a minimum vertical drop of $1400 \mathrm{~m}$. They were directed across the Lillooet River valley and, consequently, did not travel a significant distance down valley. However, the deposits can be found distributed up to $180 \mathrm{~m}$ above the paleo-Lillooet drainage on the steep opposite valley slopes, and over a lateral width of $4 \mathrm{~km}$. Based on the mapped occurrences of previous rock avalanches below Mount Meager, the area potentially affected by this type of hazard is outlined in Fig. 8a.

\subsection{Block and ash avalanches}

Block and ash avalanches are generated by the explosive or gravitational collapse of lava flows or domes induced by high strain rates that exceed the viscous limits of the lava (Voight and Davis, 2000; Woods, 2000: e.g. Rose et al., 1976; Bardintzeff, 1984; Mellors et al. 1988; Sato et al., 1992; Calder et al., 1999). At Mount Meager the transition from viscous flow to brittle failure appears to coincide with an increase in slope above the Lillooet River valley.

In general, hot block and ash avalanches feature longer runout distances than similar sized rock avalanches (e.g. Ui, 1983). This reflects the fact that lava domes and flows tend to be highly fractured and gas or fluid rich; the release and expansion of the fluid phase serves to increase the fluidity and, hence, mobility of the deposit (Ui, 1983; Siebert, 1984; Cole et al., 1999; Ui et al., 1999). In the Lillooet River valley, the deposits of block and ash avalanches and rock avalanches show very similar distributions and extensive overlap (Fig. 3). In part, the overlap simply reflects the proximity of the source regions to the volcanic and mass wasting events (Fig. 8b). Contributing to this, is the fact that both types of avalanche were directed into a steep sided valley that limited the horizontal transport distance. Avalanches dissipated their kinetic energy by climbing the opposite valley wall and by spreading laterally (upstream and downstream) relatively short distances. Lastly, Ui (1983), Hayashi and Self (1992) and Corominus (1996) have all suggested that cold rock avalanches originating from failure of volcanic massifs can have substantially greater run-out distances than would be expected of rock avalanches that sample more coherent material. The volcanic source rock tends to be less coherent and more fractured and, therefore, energy that might be consumed in fragmenting material can be used in transport. 

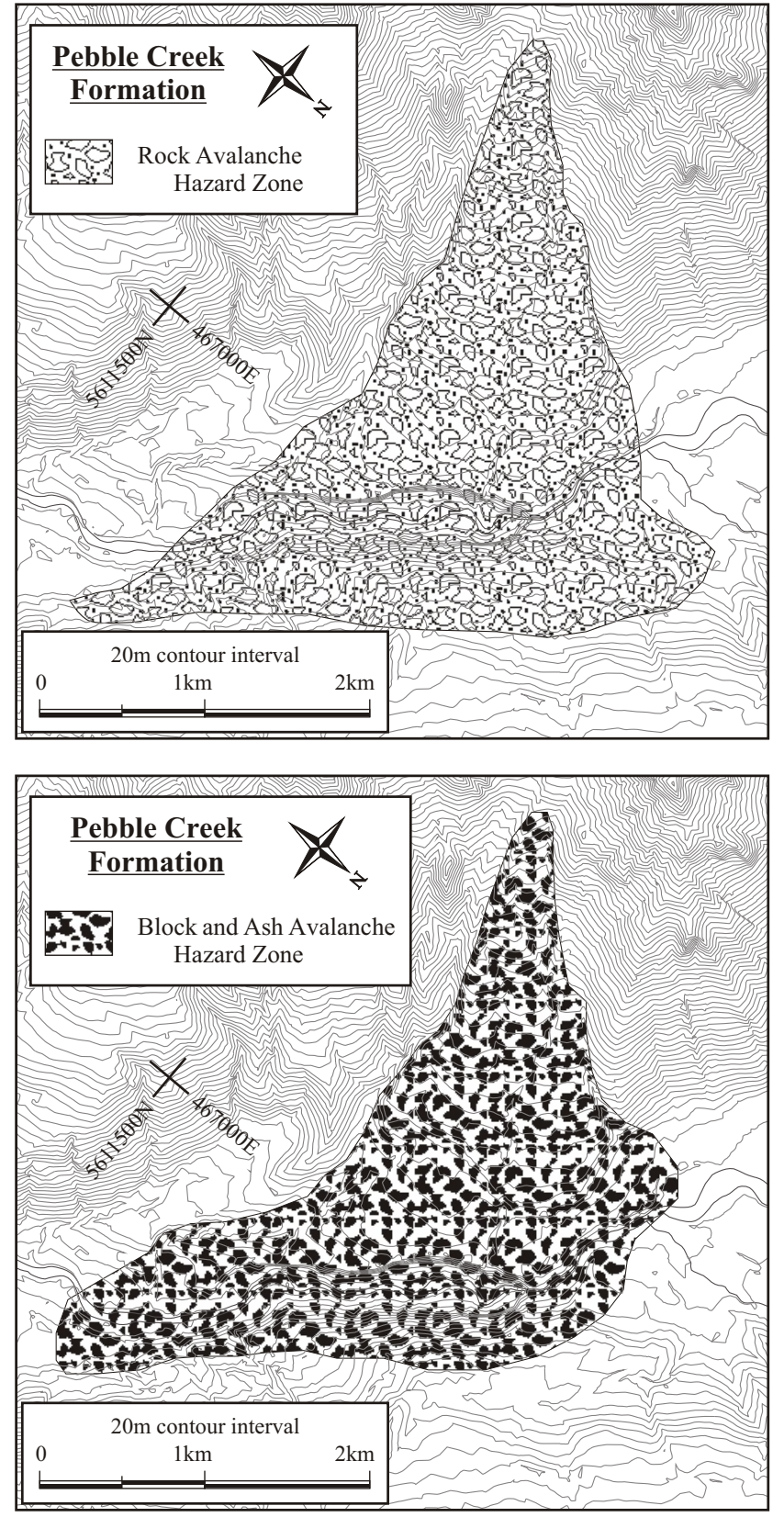

Fig. 8. The field map presented in Fig. 3 provides a basis for constructing hazard maps associated with (a) rock and (b) volcanic (b) avalanches (see Fig. 3). People and infrastructure within this area are at risk to events represented by the PCF avalanches. The head of the avalanche zones coincides with the inferred vent. The full area of impact for volcanic events cannot be mapped due to the lack of preservation of ash cloud surges and forest fires, which would likely have been spawned by the volcanic avalanche activity. Ash clouds have been known to surmount topographic barriers and travel great distances, as much as 10 times the distance of its parent volcanic flow (Rose et al., 1977; Druitt, 1998).

Although the two types of avalanches impact similar areas of the Lillooet River valley (Fig. 8), the hot volcanic events (i.e. block and ash avalanches) feature some important additional hazards. Block and ash avalanches are made up of extremely hot, viscous fragmented lava blocks, ash and hot gases. High temperatures, coupled with potentially explosive dissolved gases increase the intensity over that of cold rock avalanche hazards. In addition, the production of ash clouds can affect a much wider area than its parent block and ash avalanche (Millar and Smith, 1977; Fisher, 1990; Branney and Kokelaar, 1997; Calder et al., 1999).

During transport, highly fluidized block and ash avalanches can undergo flow transformations and density stratification from particle settling, gas elutriation and boundary layer processes (Fisher, 1979; 1995; Wilson, 1980; Druitt, 1998; Calder et al., 1999). These flow transformations can result in the formation of a density current of elutriated ash and hot gases that can decouple from the avalanche proper. It has sufficient energy and increased fluidity to travel great distances, and can surmount substantial topographic boundaries (e.g. Millar and Smith, 1977; Fisher, 1990; Branney and Kokelaar, 1997; Calder et al., 1999). Ash cloud runouts have been known to exceed the runout of its source avalanche by as much as 10 times (Rose et al., 1976; Druitt, 1998). The residual block and ash avalanche tends to flow into topographic lows and be contained by topographic barriers (Fisher, 1995; Branney and Kokelaar, 1997;). The deposits resulting from these events tend to be thin, erodible and rarely preserved in the geologic record. At Mount Meager, it is highly probable that the ash clouds traveled much farther than the block and ash avalanches, although no deposits have yet been recognized.

Both the block and ash avalanche and associated ash cloud are fast moving (up to $300 \mathrm{~m} / \mathrm{s}$ : Fink and Kieffer, 1993) and feature high magmatic gas contents, and high particle concentrations. Temperatures of the avalanche proper may be nearly magmatic (e.g. $700-1000^{\circ} \mathrm{C}$ : Cole et al., 1998 ; Voight and Davis, 2000), and temperatures of ash clouds can be high (e.g. $100-300^{\circ} \mathrm{C}$ : Voight and Davis, 2000). On this basis, avalanches from volcanic eruptions with their attendant ash clouds may cause greater damage over a wider area than rock avalanches, and a greater area than that preserved by resultant block and ash avalanche deposits.

\subsection{Event probability}

Probability distributions for geologic events are requisite for establishing a risk model. Methods for establishing rock avalanche occurrence probabilities include analysis of historic and prehistoric events and predictive forward computational models (e.g. Crovelli, 2000). Historic and prehistoric avalanche activity at Mount Meager is summarized in Table 1. Problems associated with this database include a paucity of historical data and a decreasing number of preserved deposits with increasing age. In addition, smaller events may not be recorded or may be overlooked in the stratigraphy. This could bias the data set to large events. Our data set represents a minimum number of events, providing a minimum estimate of the probability of an avalanche event 

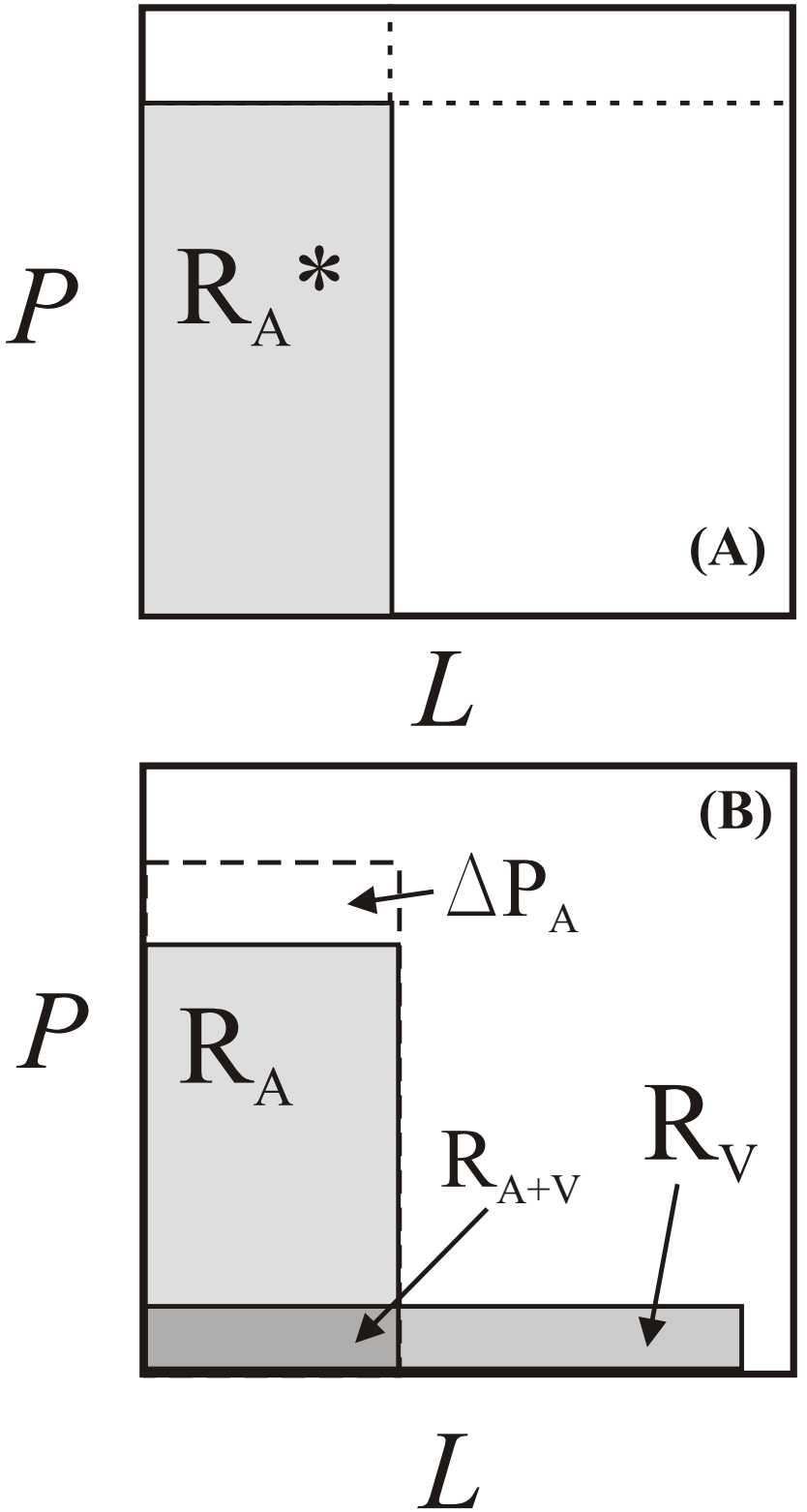

Fig. 9. Conceptual diagram for discussing relative risks associated with rock avalanches and volcanic eruptions in the Mount Meager region. Risk magnitudes (shaded areas) derive from the product of probability $(P)$ of an event within a fixed time interval and Loss $(L)$ due from the same event. (a) Risk profile $\left(R_{A}^{*}\right)$ resulting from the interpretation that all avalanche deposits represent mass wasting events (e.g. cold rock avalanche deposits). This interpretation results in a maximum estimate of $P_{A}^{*}$ and a moderate value of $L$ (see text). (b) Risk profiles resulting from proper identification of block and ash flow events (hot volcanic avalanche deposits) and discrimination from rock avalanche events. Probability of rock avalanche events is reduced (e.g. $\Delta \mathrm{P}_{\mathrm{A}}$ ) which slightly reduces the associated risk $\left(R_{A}\right)$. The probability of a volcanic event is small relative to rock avalanche events, however, the range of values of $L$ are substantially larger depending on style of eruption (e.g. effusive vs. explosive). This leads to a non-trivial risk factor $\left(R_{V}\right)$. This conceptual diagram also supports a new risk profile: the risk of contemporaneous volcanic events $\left(R_{A+V}\right)$. occurring at Mount Meager. These events are relatively frequent, independent and localized hazardous events.

Eruptive activity at stratovolcanoes is characterized by long periods of dormancy punctuated by intense and shortlived eruption cycles (e.g. Cole et al., 1998; Ui et al., 1999; Thouret et al., 2000). Each cycle is comprised of numerous individual volcanic events occurring over relatively short time intervals, such as the growth of a lava flow or the formation of a block and ash avalanche. Eruption forecasting is used to predict either long-term periodicity of eruption cycles or short term occurrences of events within an eruption cycle. Currently the most effective means of establishing probabilities for the occurrence of volcanic cycles or events is analysis of historical records, where possible, and to map the distribution, volume and ages of deposits.

Volcanic cycles recognized in the Mount Meager stratigraphy are summarized in Table 1 . This distribution is subject to the same limitations as for avalanche events including limited data due to erosion and possible errors in mapping. In addition to regular erosion from tectonic uplift, repeated glaciation (Clague et al., 1990) has affected all but the most recent volcanic deposits in the area. Most of the remaining preglacial volcanic deposits are from major edifice building volcanic cycles (Read, 1978). Smaller eruptions similar to the Pebble Creek eruption cycle may be indistinguishable from these larger episodes. Accumulations of block and ash avalanche deposits in the Lillooet River valley are greater than $100 \mathrm{~m}$ in thickness. These deposits represent at least three and likely more individual block and ash avalanche events that occurred during a relatively short eruption cycle.

Volcanic cycles comprised of these high frequency events are low frequency in comparison to rock avalanche events, but may represent a high risk to areas such as the Lillooet valley. High temperatures, the association of ash clouds and large volumes of material deposited during block and ash avalanche events all constitute an integrated volcanic hazard very distinct from that of rock avalanche events (Fig. 9).

\section{Conclusion: Implications for risk}

The risk $(R)$ of a hazardous event can be conceptualized as the product of the probability of a hazardous event occurring $(P)$ and the loss/cost $(L)$ to society, divided by how society reacts to the event through mitigation $(M)$, (Smith, 2001).

$R=\frac{P \times L}{M}$

In landscapes such as those at Mount Meager, rock avalanches are relatively common hazardous events. Stratovolcanoes such as the MMVC are inherently unstable structures. Coupled with high tectonic uplift rates in the region, the probability of a rock avalanche event at Mount Meager $\left(P_{A}\right)$ over a fixed interval of time is relatively high (Fig. 9).

The loss caused by a rock avalanche event $\left(L_{A}\right)$ is essentially proportional to the size of the rock avalanche. A conceptual representation of the risk attached to rock avalanches 
in the Mount Meager area is shown in Fig. 9. Figure 9a shows the maximum risk $\left(R_{A}^{*}\right)$ attending rock avalanche events if all monolithologic avalanche deposits in the stratigraphic record are interpreted as cold rock avalanches. We thereby maximize the probability of such an event, and as a consequence, marginally overestimate the risk of such events.

In this paper, we have established robust, field-based criteria for discriminating between volcanic and non-volcanic avalanches that have a common source (e.g. the volcanic edifice). This has implications for assessing risks associated with different natural hazards. These implications are explored schematically in Fig. 9b. Discriminating between these two types of deposits, and identifying the events properly, leads to several important changes to the risk profile in Fig. 9a. Firstly, by recognizing some of the avalanche deposits as being volcanic in origin, the number of rock avalanche deposits in the stratigraphic record is reduced. This reduces the calculated probability of such events resulting in a decrease of the assessed risk due to rock avalanche events.

Recognition of the volcanic origins of some of the avalanche deposits has other more far-reaching implications. Clearly, these data contribute to the frequency distribution curves for volcanic eruptions. By their very nature, volcanic events are substantially less frequent than rock avalanches and, therefore, the probability of volcanic events $\left(P_{V}\right)$ will be low. However, the potential for causing widespread destruction is much higher in a volcanic event than for rock avalanches. Some volcanic eruptions are associated with highly localized destruction (e.g. lava flows), but stratovolcanoes such as Mount Meager are largely products of explosive volcanism. Consequently, in consideration of the more destructive styles of volcanic eruption, the maximum value of $L$ for volcanic events $\left(L_{V}\right)$ is substantially larger than used for rock avalanches $\left(L_{A}\right)$. Although the probability of volcanism remains low, the larger values of $L$ attributable to volcanic events ensure that the associated risk $\left(R_{V}\right)$ is nontrivial.

Acknowledgements. This research was supported by the Geological Survey of Canada (CJH: Project No. 303071) and NSERC operating grant 589820 (JKR). The senior author was supported by University of British Columbia, Mineralogical Association of Canada and NSERC scholarships. We gratefully acknowledge logistical support from Garth Carefoot (Great Pacific Pumice Inc.) and fruitful discussions with and comments from M. V. Stasiuk and O. Hungr. The paper benefitted greatly from critical reviews by Steve Evans, Joan Marti and an anonymous reviewer.

\section{References}

Bardintzeff, J. M.: Merapi Volcano (Java, Indonesia) and Merapitype nuee ardente, Bulletin of Volcanology, 47/3, 433-446, 1984.

Branney, M. J. and Kokelaar, P.: Giant bed from a sustained catastrophic density current flowing over topography: Acatlan ignimbrite, Mexico, Geology, 25/2, 115-118 1997.

Calder, E. S., Cole, P. D., Dade, W. B., Druitt, T. H., Hoblitt, R. P., Huppert, H. E., Ritchie, L., Sparks, R. S. J., and Young, S. R.:
Mobility of pyroclastic flows and surges at the Soufriere Hills Volcano, Montserrat, Geophysical Research Letters, 26/5, 537540, 1999.

Cas, R. A. F. and Wright, J. V.: Volcanic Successions; Modern and Ancient, Chapman and Hall, London, 528, 1988.

Clague, J. J., Armstrong, J. E., and Mathews, W. H.: Advance of the late Wisconsin Cordilleran ice sheet in southern British Columbia since 22000 yr BP, Quaternary Research, 13, 322326,1990.

Clague, J. J., Evans, S. G., Rampton, V. N., and Woodsworth, G. J.: Improved age estimates for the White River and Bridge River tephras, Western Canada, Canadian Journal of Earth Sciences, 32/8, 1172-1179, 1995.

Clague, J. and Turner,: Vancouver, City on the edge; living with a dynamic geological landscape, Tricouni Press, Vancouver, 2003.

Cole, P. D., Calder, E. S., Druitt, T. H., Hoblitt, R., Robertson, R. A. E., Sparks, R. S. J., and Yound, S. R.: Pyroclastic flows generated by gravitational instability of the 1996-1997 lava dome of the Soufriere Hills volcano, Montserrat, Geophysical Research Letters, 25, 3425-3428, 1998.

Corominas, J.: The angle of reach as a mobility index for small and large landslides, Canadian Geotechnical Journal, 33, 260-271, 1996.

Crovelli, R. A.: Probability models for the estimation of number and costs of landslides, USGS Open File Report 00-249, 2000.

Dingwell, D. B. and Webb, S. L.: Relaxation in silicate melts, European Journal of Mineralogy, 2, 427-449 1990.

Druitt, T. H.: Pyroclastic density currents, in: The Physics of Explosive Volcanic Eruptions, edited by Gilbert, J. S. and Sparks, R. S. J., Geological Society, London, Special Publications, 145, 145-182, 1998.

Erismann, T. H. and Abele, G.: Dynamics of Rockslides and Rockfalls, Springer, New York, 316, 2001.

Farley, K. A., Rusmore, M. E., and Bogue, S. W.: Post-10 Ma uplift and exhumation of the northern Coast Mountains, British Columbia, Geology, 29/2, 99-102, 2001.

Fink, J. H. and Kieffer, S. W.: Estimates of flow velocities resulting from explosive decompression of lava domes, Nature, 363, 612615, 1993.

Fisher, R. V.: Models for pyroclastic surges and pyroclastic flows, Journal of Volcanology and Geothermal Research, 6, 305-318, 1979.

Fisher, R. V.: Transport and deposition of a pyroclastic surge across an area of high relief: the 18 May 1980 eruption of Mount St. Helens, Washington, Geological Society of America Bulletin, 102, 1038-1054, 1990.

Fisher, R. V.: Decoupling of pyroclastic currents; hazards assessments, Journal of Volcanology and Geothermal Research, 66, 1/4, 257-263, 1995.

Green, N. L., Armstrong, R. L., Harakal, J. E., Souther, J. G., and Read, P. B.: Eruptive history and K-Ar geochronology of the late Cenozoic Garibaldi volcanic belt, southwestern British Columbia, Geological Society of America Bulletin, 100, 563579,1988

Hayashi, J. N. and Self, S.: A comparison of pyroclastic flow mobility and debris avalanche mobility, Journal of Geophysical Research, 97/B6, 9063-9071, 1992.

Hickson, C. J., Russell, J. K., and Stasiuk, M. V.: Volcanology of the 2350 B.P. eruption of Mount Meager Volcanic Complex, British Columbia, Canada: implications for hazards from eruptions in topographically complex terrain, Bulletin of Volcanology, 60 , 489-507, 1999. 
Hsü, K. J.: Catastrophic debris streams (sturzstroms) generated by rockfalls, Geological Society of America, Bulletin, 86, 129-140, 1975.

Hungr, O.: Mobility of rock avalanches, Report of the National Research Institute for Earth Sciences and Disaster Prevention, 46, 11-20, 1990.

Mellors, R. A., Waitt, R. B., and Swanson, D. A.: Generation of pyroclastic flows and surges by hot-rock avalanches from the dome of Mount St. Helens volcano, USA, Bulletin of Volcanology, 50, 14-25, 1988.

Melosh, H. J.: Acoustic fluidization: a new geologic process? J. Geophys. Res., 84, 7513-7520, 1979.

Miller, T. P. and Smith, R. L.: Spectacular mobility of ash flows around Aniakchak and Fisher calderas, Alaska, Geology, 5, 173176, 1977.

Read, P. B.: Geology of Meager Creek geothermal area, British Columbia, Geological Survey of Canada, Open File 603, 1978.

Rose, W. I., Pearson, T., and Bonis, S.: Nuée ardente eruption from the foot of a dacite lava flow, Santiaguito Volcano, Guatemala, Bulletin Volcanologique, 40/1, 23-38, 1976.

Sato, H., Fujii, T., and Nakada, S.: Crumbling of dacite dome lava and generation of pyroclastic flows at Unzen volcano, Nature, 360/17, 664-666, 1992.

Scheidegger, A.: On the prediction of the reach and velocity of catastrophic landslides, Rock Mechanics, 5, 231-236, 1973.

Siebert, L.: Large volcanic debris avalanches: characteristics of source areas, deposits, and associated eruptions, Journal of Volcanology and Geothermal Research, 22, 163-197, 1984.

Smith, K.: Environmental Hazards: Assessing Risk and Reducing Disaster, London, Routledge, 2001.

Stasiuk, M. V. and Russell, J. K.: Petrography and chemistry of the Meager Mountain volcanic complex, southwestern British Columbia, in: Current Research, Part E, Geological Survey Of Canada, 89-01E, 189-196, 1989.

Stasiuk, M. V. and Russell, J. K.: The Bridge River assemblage in the Meager Mountain volcanic complex, southwestern British Columbia, in: Current Research, Part E, Geological Survey of Canada, 90-1E, 153-157, 1990.

Stewart, M. L., Russell, J. K., and Hickson, C. J.: Revised stratigraphy of the Pebble Creek Formation, British Columbia: evidence for interplay between volcanism and mountainous terrain, in: Current Res., Geolog. Survey of Canada, 2002-E3, 7, 2002.

Stoopes, G. R. and Sheridan, M. F.: Giant debris avalanches from the Colima volcanic complex, Mexico; implications for longrunout landslides $(>100 \mathrm{~km})$ and hazard assessment, Geology, 20/4, 299-302, 1992.

Thouret, J. C., Lavigne, F., Kelfoun, K., and Bronto, S.: Toward a revised hazard assessment at Merapi Volcano, central Java, J. Volcanol., 100/1-4, 479-502, 2000.

Ui, T.: Volcanic dry avalanche deposits - identification and comparison with nonvolcanic debris stream deposits, J. Volcanol., 18, 135-150, 1983.

Ui, T., Matsuwo, N., Sumita, M., and Fujinawa, A.: Generation of block and ash flows during the 1990-1995 eruption of Unzen Volcano, Japan, J. Volcanol., 89, 123-127, 1999.

Voight, B. and Davis, M. J.: Emplacement temperatures of the 22 November 1994 nuee ardente deposits, Merapi Volcano, Java, J. Volcanol., 100, 371-377, 2000.

Voight, B., Janda, R. J., Glicken, H., and Douglass, P. M.: Nature and mechanics of the Mount St. Helens rockslide-avalanche of 18 May 1980, Geotechnique, 33, 243-273, 1983.

Walker, G. P. L.: The breaking of magma, Geological Magazine, 106/2, 166-173, 1969.

Wilson, C. J. N.: The role of fluidization in the emplacement of pyroclastic flows: an experimental approach, J. Volcanol., 8, 231249, 1980.

Woods, A. W.: The dynamics of hazardous volcanic flows, Philosophical Transactions of the Royal Society of London, 358, 1705-1724, 2000. 